\title{
Kehendak Bebas Dalam Pandangan Para Filsuf Sebuah Problem Bidang Etika
}

\author{
Oleh : Fahmi Muqoddas
}

\begin{tabular}{|l|l|} 
FahmIMuqoddas, Iahirdi Yogyakarta 29 Januari \\
1945 Alumni.Fak. Filsafat UGM dan Fak. Syariah \\
IAIN SUKA Dosen pada Fak. Ushuluddin IAIN \\
SUKA bidang Filsafat dan Dosen di UII sejak \\
1976 sampaisekarang. Pernah menjabat sebagai \\
Pembantu Dekan IIIFak. Tehnik Tekstil UIITahun \\
1977 - 1980. Sekarang sedang menempuh S2 \\
UGM bidang studi ilmu Filsafat
\end{tabular}

\section{Pendahuluan}

Apakah manusia itu memiliki kehendak bebas atau tidak didalam perjalanan hidupnya ? Persoalan yang tampaknya sederhana ini ternyata mengundang tanggapan yang luas sekaligus rumit, baik di dalam bidang filsafat maupun di dalam bidang agama. Oleh karena itu penulusuran terhadap pembahasan mengenai kehendak bebas ini menjadi sangat menarik, sebab di samping melibatkan berbagai unsur yanglain seperti peranan rasio dalam diri manusia, ia juga membawa konsekwensi terhadap pandangan hidup dan keyakinan agama yang'dianuat seseorang.

Dalam perjalanan sejarah filsafat telah banyak filsuf yang berusaha mengungkap peranan kehendak ini dalam diri manusia, namun tidak pemah terçapai suatu kesepakatan pengertian secara umum. Walaupun banyak pandangan mengenai peranan kehendak ini, namun pada umumnya dapat diklasifikasikan ke dalam dua aliran besar, yaitu determinisme dan indeterminisme. Menurut pandangan determinisme, manusia tidak memiliki kehendak bebas dalam menentukan prinsipprinsip pokokmoralitas di dalam hidupnya. sedangkan indeterminisme menganggap bahwa manusia memiliki kehendak bebas untuk menentukan prinsip-prinsip pokok moralitas tersebut. Di dalam terminologi filsafat Islam, determinisme dikenal sebagai jabariah, sedangkan indeterminisme disebut Qadariah. (Harun Nasution, 1983) -

Kedua aliran ini mempunyai sederetan pengikut, baik yang fanatik maupun sekedar simpatisan. baik disadari ataupun tidak, kita termasuk salah satu dari kedua aliran tersebut. Oleh karena itu membicarakan kedua aliran ini berarti kita membicarakan pandangan hidup, paling tidak pendirian kita. 
Pengertian Kehendak Bebas.

Istilah kehéndak dalam kamus Poerwadarminta berarti kemauan atau keinginan dan harapan keras. (Poerwadarminta, 1987). Menurut Lorens Bagus, istilah kehendak ini (dalam bahasa Inggris berarti.Will; Latin, Voluntas; Yunani, Boúlema) mengacu kepada suatu potensi, fakultas, atau daya di dalam manusia yang terlibat di dal am pengambilan keputusan. (Lorens Bagus, 1992). Kehendak dapat juga mengandung arti menyetujui atau tidak setuju terhadap sesuatu pilihan, hasrat atau kebenaran. (Ali Mudhafir, 1992).

Sedangkan istilah bebas (dalam bahasa inggris bebas berarti free) mengacu pada kemandirian atau kemampuan untuk menentukan diri dari mahluk rasional. (Dogert D. Runes, 1979).

Manakala kedua istilah itù dipadukan menjädi kehendak bebas (free will), maka ia mengandung arti sebagai daya mahluk rohani untuk menentukan dirinya berkenan dengan nilai-nilai yang diketahui, yāng terbatas (artinya scbelumnya tidak ditentukan nilai mana yang diambil). Istilah kehendak bebas menurut Lorens Bagus, adalah kckuatan mahluk rohani untuk memilih atau tidak memilih kebaikan yang terbatas. Karena itu baru ada pertanyaan mengenai kehendak bebas manakala sebuah nilai dipandang real, tetapi terbatas dan karenanya tidak tcrikat pada ketidak scmpumaan, maka kehendak mutlak harus mengafirmasikan dan mencarikcbaikan ini (Lorens Bagus, 1992).

Sedangkan Runes menegaskan kchendak bebas ini dilawankan dengan faham determinisme, yang menganggap bahwa kebebasan kehendak manusia itu dalam pengertian sebagai berikut :
1. Kebebasanuntuk tidak ditentukan, yaitu kemerdekaan yang dinyatakan keinginan dari kondisi anteseden, psikologis, dan. fisiologis. suatu kehendak bebas dalam pengertian ini merupakan bagian yang tidak disebabkan atau tidak dihubungkan menurut suatu cara yang seragam dengan karakter perantara, motif-motif dan keadaan-keadaan.

2. Kebebasan memilih alternatif yang terkandung di dalam kemampuan menduga dari perantara untuk memilih di antara berbagai kemungkinan alternatif tindakan.

3. Kebebasan menentukan diri sendiri terkandung di dalam kemerdekaan untuk memutuskan dari paksaan atau ketidak leluasaan eksternal, tetapi di dalam kesesuaian dengan motif-motif bathiniah dan ideal dari perantara. (Runes, 1979)

Di antara ketigapengertian kehendak bebas diatas maka pengertian yang ketiga lebih mengena pada masalah moral. Istilahi kehendak bebas ini memang paling intens dipergunakan dalam hubungannya dengan kegiatan etis.

+ Apakahmanusia memiliki kehendak bcbas dalam menentukan keputusankeputusan moral ? Kalau manusia tidak memiliki kchendak bebas dalam menentukan keputusan-keputusan moral, dapatkah manusia itu diminta pertanggungan jawab? bagaimana hubungan antara kchendak bebas ini dengan tanggung jawab pribadi manusia scbagai mahluk ciptaan Tuhan? Apakah manusia scbagai khalifatullah fil ardli sepenuhnya memiliki kehendak bebas untuk memilih apa yang seharusnya ia lakukan? Kesemuanya ini-merupakan problema 
filosofis yang mengundang perdebatan panjang dalam perjalanan sejarah filsafat. Oleh karena itu kita akan coba menelusuri pandangan beberapa filsuf dan aliran filsafat yang concern terhadap peranan kehendak bebas ini dalam eksistensi manusia.

\section{Pandangan Para Filsuf Tentang Kehendak Bebas.}

Dunia ini penuh" hal yang mengagumkan, tetapi tidak ada yang lebih mengagumkan daripada manusia, demikian ujar Sophocles. (Conny S., 1991). manusia memang tidak hanya mengagumkan, tetapi mengandung misteri yang tidak cukup diungkap dari aspek fisiologis semata. ( Alexis Careel, 1987):

Kekaguman dan tabir misteri ini semakin menebal manakala kita coba mengungkap salah satu unsur dalam aktivitas jiwa manusia, yaitu kehendak. Berikut ini akan diketengahkan pandangan beberpa filsuf tentang kehendak.

\section{Plato (427-347 SM); Menurut} pandanganya jiwa manusia dapat dibagi ke dalam tiga fungsi, yaitu keinginan dan kemauan (epithymia), energik (thymos) dan räsional (logos). Jika keinginan serta energi di bawah pimpinan rasio dapat berkembang dengan semestinya, maka akan timbul manusia yang harmonis dan adil. (Van der Weij, 1988).

Plato menganalogikan keinginan (epithymia) ini dengan buruh, petani dan pedagang sebagai golongan yang produktif, energi (thymos) dianalogikan dengan prajurit sebagai golongan penjaga, sedangkan rasional (logos) dianalogikan dengan pejabat sebagai pemegang pucuk pimpinan tertinggi. Dengan demikian terlihat jelas bahwa rasio sebagai pemegang keputusan. Pcranan akal lebih tinggi daripada kehendak. namun peranan kehendak selalu dibutuhkan oleh akal, terutama untuk pendorong timbulnya cinta (eros). menurut Plato eros adalah daya kreatif dalam dirimanusia, pencetuskehidupan, inspirator para penemu, seniman dan genius. (Van der Weij, 1988).

Disini kita melihat bahwa Plato meletakkan peranan kehendak pada bidang epistimologis.

2. Aristoteles ( $384-322 \mathrm{SM})$; Ia menggantungkan problema " kehendak " itu dalam keutamaan. Keutamaan adalah perwujudan kemungkinankemungkinan baik dari manusia. (Van der Weij, 1988). Ini berarti bahwa manusia memiliki potensi untuk mencapai keutamaan dan mewujudkan dạlam tindakan. Bagi Aristoteles, kebahagiaan sempurna adalah mempraktckan keutamaan tertinggi, yakni mewujudkan "yang paling baik" dalam diri kita, yaitu bakat rasional kita. Dengan kata lain, bagi Aristoteles - manusia memiliki potensi untuk berbuat baik.

Aristoteles tidak menyinggung peranan-kehendak bebas dalam diri manusia dan yang diutamakan adalah potensi dalam diri manusia untuk mencapai keutamaan. Keutamaan dan kejelekan kedua-duanya merupakan sesuatu yang bisa kita raih. Memang orang dapat terbiasa dengan pilihan, tetapi menjadi tanggung jawabnya, bahwa ia membiasakan diri pada yang baik itu sejak awal. (Sudihardjo, 1993).

3. Agustinus, $(354 \div 430)$; - Prinsip dasar etika Agustinus mengikuti etika Plato dan Aristoteles, yakni eudemonisme dan 
teleologis, artinya kebaikan diukur dari tujuan mencari kebahagiaan,dengán mengupayakan keutamaan-keutamaan. Keutamaan ini berasal dari Tuhan. Bagi Agustinus, kebebasan adalah mutlak. Manusia bebas mengarahkan jiwanya menuju kebaikan tetap (immutable good), atau kebaikan-kebaikan semu (mutable good). Meskipun ada kebebasan manusia diberi pengetahuan mengenai kebenaran, mengenai hukumhukum Tuhan untuk diikuti. Tuhan yang merupakan sumberkebaikan yang tetap, kebahagiaan abadi, Pengetahuantentang kebenaran yang mengarahkan pada kebahagiaan inipun ditanamkan Tuhan dalam diri manusia dalam hạtinya, (Sudihardjo, 1993).

Dengan demikian pada diri manusia terdapat kebebasan untuk berbuat dan pada sisi yang lain dalam diri manusia tertanam pengetahuan kebenaran.

4. Thomas Aquinas (1225-1274); Seorang filsuf pada zaman pertengahan yang menginterprestasi ajaran Aristoteles dalam konteks agama Kristiani; menurut pandangannya 'manusia adalah gabungan dari dua subtansi yang tidak lengkap, yaitu materi pertama dan jiwa. Manusia adalah tubuhnya yang hidup, bersama dengan semua gejala dan aktifitasnya. Jiwa dianggap Thomas semata-mata rohani, tunggal, prinsip hidup dari seluruh manusia dan tidak dapat mati. Ketakjasmanian jiwa terutama tampak dari ketakjasmanian kegiatan-kegiatan lebih tinggi, yaitu berfikir dan berkehendak. (Van der Weij, 1988). Jadi kehendak dalam pandangannya ini termasuk dalam salah satu unsur jiwa, di samping penikiran. yang melakukan aktifitas kejasmanian.
Kehendak ini tercipta dalam jiwa manusia karena campur tangan Tuhan. Apa yang mendorong timbulnya tindăkan pada manusia ? hasrat atau keinginan untuk mengejar kebahagiaan itulah yang mendorong tindakan manusia. Namun pengejaran kebahagiaan ini oleh manusia tidak dipilih atau ditentukan oleh manusia secara sukarela. karena menupakan suatu potensi dalam dirinya yang melampaui kemampuannya. Jadi manusia tinggal mengembangkan saja. Dalam bidang Etika, corak pandangan yang demikian ini disebut etika hukum kodrat, yang dapat mengizinkan sebuah pluralisme moralitas. Prinsip dasar etika hukum kodrat ini berbunyi : "Bonum est faciendum et prosequendum, et malum vitandum "(Yang baik harus dilakkukan dan diusahakan, dan yang buruk dihindari). Kodrat dalam hal-ini dimodifikasi oleh kekhasan situasi dan kondisi. Sesuatu yang sesuai dengan kodrat berarti sesuai dengan tujuan terakhir, yaitu kebahagiaan. (Magnis S. 1992).

5. Thomas Hobbes (1588 - 1679); Menurut pandangannya kehendak ini identik dengan nafsu. Kehendak merupakan mata rantai terakhir dari rangkaian nafsu yang menuju tindakan. Dalam keadaan alamiah tindakan manusia itu buas (homo homini lupus). karena dalam keadaan perjuangan dan peperangan terus ménerus. Oleh karena itu manusia menginginkan kelang-sungan hidupdan perdamaian, maka ia mengalihkan kemauannya (kehendaknya) kepada kemauan negara dalam suatu kontrak sosial yang membenarkan kekuasaan yang tertinggi dan mutlak (Titus, Smith 
dan Nolan 1984).

6. Immanuel Kant (1724 ; 1804 ); Membicarakan tentang kehendak bebas tanpa menyinggung nama besar Kant dapat dianggap sebagai pelecehan terhadap penulisan sejarah filsafat barat. Menurut Kant, tujuan moralitas adalah kebaikan tertinggi (summun bonum), dan kebaikan tertinggi berarti kebahagiaan sempuma. Namun menurut Kant, di dunia ini kebaikan tertinggi tidak akan pernah secara penuh, karena adanya kejahatan. Kendatipun demikian tujuan itu wajib dikejar oleh tindakan manusia yang bermoral. sikap ini menimbulkan pertanyaan, kalau kebaikan tertinggi itu tidak akan pernah tercapai di dunia ini padahal ia wajib dikejar apakahi tindakan manusia yang bermoral itu tidak sia-sia adanya? Kant menjawab, persoalan ini dengan tegas, agar kebaikan moral manusia ini tidak sia-sia berkait dengan kebahagiaan sempuma, maka kita harus menerima adanya tiga postulat, yaitu kehendak bebas, immortalitas jiwa, dan Tuhan. (Lili Tjahyadi, 1991). Suatu kewajiban moral yang tidak menyertakan kebebasan, kehendak merupakan hal yang mustahil. Hukum moral itu mengandaikan adanya ótonomi dalam diri manusiauntukmelakukan seseorang dapat dimintai pertanggungan jawab.

Sedangkan immortalitas jiwa mèngakibatkan manusia sebagai pelaku tindakan moral bisa mencapai summum bonum yang tidak mungkin dicapainya di dunia ini. Akhimya tuntutan mutlak tentang hidup moral yang baik akan tidakmemuaskan bila tidakadaganjaran yang adil dan bijaksana bagi yang baik dan jahat. Suatu perbuatan harus mendapat ganjaran yang setimpal. Maka haruslah pada seorang pribadi yang maha adil, yang memberikan sanksi bagi tindakan yang tidak baik.Hanya Allah, kata Kant, yang dapat menciptakan kebahagiaàn sempurna bagi manusia yang baik di alam semesta. (Lili Tjahyadi, 1991)

7. Qadariah. Salah. seorang yang menyebarkan faham ini adalah Ghailan Dimasyqi. Istilah qadariyah ini berasal dari bahasa Arab dengan. akar kata 'qadara' yang mengandung dua arti, yaitu (1) Kuasa, memandang manusia berkuasa dan bebas dalam perbuatannya; (2) Menentukan, memandang bahwa nasib manusia telah ditentukan tuhan sejak zaman azali (Azyumardi Azra, 1987). Faham qadariah yang dimaksud disini mengacu pada arti 'qadara' yang pertama.

Menurut Tarikh Islam, faham ini telah ada pada zaman Nabi Muhammad saw, sebab dalam suatu hadits, belaiau pemah berkatan : "Al-Qadariyatu majusu Hadzihi al-Ummah" (Kaum Qadariyah itu majusinya umat Islam). Sedangkan pada perjalanan sejarah Islam berikutnya, faham Qadariah ini berkaitan erat dengan Mu'tazilah. Qadariah sangat menitik beratkan tanggung jawab manusia atas setiap perbuatannya. Mereka menolak -paham yang berpendapat bahawa Tuhan berkuasa mutlak ațas setiap perbuatan manusia. Menurut mereka, akal yang diberikan Tuhan pada manusia, mampu membedakan atau memilih mana perbuatan yang baik dan mana yang buruk. Dengan kemampuan dan kebebasan itulah manusia berkuasa (qadara) menentukan nasibnya sendiri. 
Dengan demikian setiap perbuatan manusia, baik atau buruk, beriman atau kufur, ditentukan oleh manusia itu. sendiri. (Azyumardi Azra, 1987). Menurut faham Qadariah ini manusia -mempunyai kemerdekaan dan kebebasan dalam menentukan perjalanan hidupnya. Manusia mempunyai qudrah atau kekuatan (kehendak bebas) untuk melaksanakan kehendaknya: Dalam istilah Inggeris faham ini dikenal dengan nama Free Will dan Free Act. (Harun Nasution, 1983).

Menurut Ghailan, tokoh aliran ini, manusia berkuasà atas perbuatanperbuatan baik atas kehendak dan kekuasaannya sendiri dan manusia sendiri pula yang melakukan atau menjauhi perbuatan-perbuatannya ; manusia sendirilah yang melakukan perbuatan-perbuatan baik atas kehendak dankekuasaanya sendiri dan manusia sendiri pula yang melakukan atau menjauhi perbuatan-perbuatan jahat atas kemauan dan dayanya sendiri. (Haṛun Nasution, 1983).

Gerak perbuatan manusia menurut faham ini dibagi atas dua bagian; gerak sadar (harakah ikhtiariah) dan gerak tidak sadar (harakah idhtiariah). Secara sadar manusia memiliki kemampuan untuk membedakan kedua atau. kehendak manusia misalnya gerak tangan mengambil sesuatu sesuai dengan perintah otak dan kemauan (dalam dunia modern terutama di bidang medis, ditemukan adanya penyakit yang membuktikan bahwa àntara perintah otak dan kemauan dapat terjadi perbedaan;misalriya seseorang yang mengindap penyakit syaraf tertentu ingin atau berkehendak mengambil sesuatu, tetapi otak memberikan perintah yang lain, sehingga benda yang diambil juga berbeda). Sedangkan gerak tidak sadar berada di luar kontrol otak, kemauan dan kekuasaan manusia, misalnya gerak tangan atau tubuh ketika menggigil kedinginan atau gerak refleks lainnya.

Perbedaan gerak laku perbuatan manusia ini menimbulkan konsekuensi pada tanggung jawab moral manusia. Jika manusiabukan menciptakan sendiri gerak sadar dalam perbuatannya, maka gugurlah tanggung jawab atas dirinya. Bila manusia tidak memiliki kekuasaan dan kemampuan untuk berbuat dan'tidak berbuat', tidaklah dapat diterima akal kalau perintah dijatuhkan kepadanya untuk melakukan suatu perbuatan. Dengan demikian tidak dapat dikenakan pahala dan dosa atau pujian dan celaan kepada manusia. Di sini terlihat salah satu argumentasi yang diajukan penganut faham qadariyah untuk membuktikan bahwa manusia memiliki kehendak bebas yang sangat berbeda dengan prinsip penganut faham Jabariyah berikut ini.

8. Jabariyah; tokoh yang tersohor dari aliran ini adalah jahm ibn Safwan. Istilah jabariyah ini berasal dari bahasa Arab dengan akar kata 'Jabara' yang mengandung arti "alzamahu bifi'lihi", manusia itu berkewajiban atau terpaksa dalam perbuatannya. Menurut faham ini manusia tidak mempunyai kemerdekaan dalam menentukan kchendak dan perbuatrnya. Manusia itu terikat pada kehendak mutlak (iradah) Allah. Perbuatan-perbuatan manusia telah ditentukan dari semula oleh qadha dan qadarTuhan(Harin Nasution, 1983) 
Jahm ibn Safwan, tookoh aliran ini, mengemukakan bahwa manusia tidak mempunyai kodrat atas apapun dan tidak disifati dengan kemampuan. Manusia sama sekali terpaksạ atas perbuatannya, tidak punya kodrat, tidak punya iradat, dan tidak punya pilihan. Manusia tidak dapat bertindak selain pekerjaan yang telah ditentukan Tuhan baginya. Segala perbuatań manusia itu pada hakikànya merupakan ciptaan Allah, sama seperti gerak yang terjadi pada benda mati. Jika dinisbahkan kepada manusia suatu gerak dan perbuatan, 'maka itu hanya dinisbahkkan kepada benda mati, seperti pohon berbuah, air mengalir, matahari terbit dan tenggelam, langit mendung dan menurunkan hujan, bumi merekah dan menumbuhkan tanaman. (Azyumardi Azra, 1987).

Menurut faham ekstrim ini, segala perbuatan manusia tidak merupakan perbuatan yang timbul dari kemauannya sendiri, tetapi perbuatan yang dipaksakan atas dirinya. kalau seseorang mencuri umpamanya, maka perbuatan mencuri itu bukanlah terjadi atas kehendaknya sendiri, tetapi timbul karena qadha dan qadar Tuhan yang menghendaki demikian. Jadi ia mencuri bukanlah atas kehendaknya, tetapi Tuhanlah yang memaksanya mencuri. Manusia dalam faham ini, hanya merupakan wayang yang digerákkan oleh Tuhan. Tanpa gerak dari Tuhan manusia tidak bisa berbuat apa-apa (Harun Nasution, 1983).

Lalu, di manaletakperanan kehendak bebas itu dalam eksistensi manusia? Di dạlam faham Jabariyah ini kehendak bebas tidak berperan atau boleh dikata kecil sekali:MenurutSyahrastani, faham
Jabariyah ini dapat diklasifikasikan ke dalam dua kélompok. Kelompok pertama, jabariyah murni, berpendapat bahwa baik tindakan maupun kemampuan manusia untuk melakukansuatu kemauan (kehendak bebas) atau perbuatannya tidak efektif sama sekali. Atau dengan kata lain, jabariyah murni menolak peran kehendak bebas dalam eksistensi manusia. Kelompok kedua, jabariyah moderat, berpandangan bahwa manusia mempunyai sedikit kemampuan untuk mewujudkan kehendak dan perbuatannya. Jabariyah moderat yang dikembangkan oleh Hussein Ibnu Muhammad Al Najjar (Najjariyah) dan Dhirar Ibn Amir (Dhirariyah) berpendapat bahwa Tuhanlah yang menciptakàn perbuatan manusia baik dan burưk, tetapi manusia mempunyai peranan dalam mewujudkan perbuatan-perbuatan tersebut. Tenaga yang diciptakan Tuhan dalam diri manusia mempunyai daya untuk mewujudkan perbuatannya. Daya itu disebut kasb (Acqisition). Dengan adanya daya itu, manusia tidak lagi semata-mata terpaksa - dalam perbuatannya, bahkan ia "bekerjasama" dengan Tuhan dalam berbuat dan bertindak. (Azyumardi Azra, 1987).

9. Muhammadlqbal,(1977-1938); seorang interpretator ulung (dalam terminologi agama, beliau disebut mujtahid atau reformator pembaharu). Ia juga melontarkan pandangan-pandangannya mengenai kehendak bebas dalam upaya untuk menginterprestasi ajaran Islam tentang perbuatan manusia. Menurutnya makhluk yang gerakkannya ditentukan sepenuhnya seperti sebuah mesin, tidak 
mungkin akan menghasilkan kebaikan.

Karena itu kemerdekaan (kehendak bebas) adalah syarat kebaikan. Bahwa Tuhan mengambil resiko ini memperlihatkan kepercayaan-Nya pada manusia. (Djohan Effendi, 1987).

Upaya Iqbal untuk mengungkap tentang kehendak bebas (ego merdeka) ini dalam kaitannya dengan kejatuhan Adam dan Hawa dari surga ke bumi adalah sebagai berikut: "Jadi kita lihat bahwa dongeng Qur'an tentang kejatuhan Adam tak ada hubungannya dengan munculnya manusia buat pertama kali di Planet ini. Qur'an bermaksud menunjukkan kebangkitan manusia dari suatu keadaan primitif dengan selera nalurinya menuju kesadaran bahwa ia memiliki suatu ego yang merdeka, yang mampu untuk bersikap ragu-ragú dan mampu pula untuk membangkang. Kejatuhan manusia tidak berarti kejatuhan moral, melainkan merupakan perubahan dari kesadaran yang bersahaja menuju cahaya pertamakesadarandiri,semacam terbangun dari mimpi alam karena mendengar debaran kausalitas pribadi dalam hidupnya sendiri". (Muhammad Iqbal, 1966).

Ego yang merdeka, yang mampu bersikap ragu-ragu dan mampu pula untuk membangkang, ituidentikdengan kehendak bebas. Dengan demikian kita melihat jelas bahwa dalam pandangan Iqbal, kehendak bebas ini memainkan peranan yang sangat menonjol dalam eksistensi manusia, teírutama dalam putusan moral. Betapa pentingnya kemerdekaan (kehendak bebas) ini bagi manusia, sehingga menurut Iqbal, perbuatan ingkar manusia pertama (Adam dan Hawa memakan buah terlarang) adalah perbuatan pertamanyauntuk memilih secara merdeka; dan itulah sebabnya Qur'an berpendapat bahwa pelanggaran Adam yang pertama itu, diampuni. Karena itu kebaikan bukanlah persoalan keterpaksaan, melainkan penyerahan ego secara merdeka kepada cita-cita moral; kebaikan itu juga berasal dari suatu kerjasama ikhlas antar ego-ego yangmerdeka. (Muhammad Iqbal, 1966). Jadi sebagaimana pula halnya dengan Kant, Iqbal menerima kemerdekaan itu sebagai syarat kebaikan, kebebasan kehendak merupakan Postulat bagi suatu perbuatan moral.

\section{Penutup/Evaluasi Kritis}

Berbicara tentang etika, maka free will merupakan persoalan sentral yang menjadi pembicaraan para filsuf yang tidak pernah akan selesai bahkan semakin hangat: Sebagian filsuf mengemukakan pentingnya peran kehendak- bebas dalam perbuatan manusia dan sebagian lain menentang peran kehendak bebas, di samping mereka yang tampaknya mengambil jalan tengah.

Mereka yang berpendapat bahwa manusia bebas dalam perbuatannya dikenal dengan indeterminisme yang dalam filsafat Islam dikenal dengan Qadariyah, sedangkan mereka yang berpendapat bahwa manusia tidak bebas berbuat disebut determinisme atau Jabariyah.

Menurut hemat saya bahwa kedua kubu, indeterminisme dan determinisme, menggambarkan dua kubu yang tajam dan tampak bertentangan secara ekstrim. Indenterminisme menempatkan free will sebagai sesuatu yang menentukan perbuatan-perbuatan manusia sehingga seakan-akan manusia seperti "Tuhan kecil" (Mikro Theos) menurut istilah Berdyaev. 
Kemudian determinisme menggambarkan peran Tuhan secara tajam dan tidak ada peran sama sekali pada diri manusia sehingga unsur kreativitas manusia terabaikan. Hal ini bisa menjurus ke arah fatalistik. Sesungguhnya Tuhan menciptakan manusia dengan suatu maksud (rencana). Dia menciptakan dengan Qudrat dạn Iradat-Nya yang mengejawantah dalam diri manusia sebagai sebaik-baik makhluk (ahsanittaqwim).

Manusia adalah makhluk yang dibalik keterbatasannya, juga memiliki kelebihan atau keistimewaan berupa sifatsifat ke-Tuhanan (theomorfis). Keterbatasan manusia itu justru untuk menunjukkan bahwa manusia itu adalah ciptaan Tuhan dan bukan pencipta (Khaliq). Sedangkan kelebihan dan keistimewaannya untuk membuktikan bahwa manusia itu merupakan wakil Tuhan di muka bumi (Khalifah fil ardl) yang mengemban amanat-Nya.

- Manusia oleh Tuhan diberi daya pembeda antara mana yang baik dan mana yang buruk, dan inilah karunia (potensi) besar pemberian Tuhan kepada manusia sesuai dengan kapasitasnya sebagai khalifah fil ardl dan sekaligus jati diri manusia. Allah tidakmembiarkan diri manusiauntuk mengembangkan daya pembeda itu sesuai dengan keinginan sendiri tetapi dibimbing dengan diutusnya para Rasul Tuhan yang membawa Kitab. Dengan demikian manusia diberi kesempatan untuk mengembangkan daya pembeda tadi secara kritis dan dikembangkan sesuai dengan petunjuk Tuhan.

Menyadari akan keterbatasan manusia dalam menentukan baik dan buruk secara individual maka kiranya perlu dibangun suatu komunitas yang menegakkan tradisi saling ingat mengingatkan dengan membuka dialog. Dandisinilah peran pemuka-pemuka agana untuk ikut bertanggung jawab melunuskan serta mengarahkan perilaku manusia dan masyarakat agar tetap menegakkan kebaikan dan menjauhi yang buruk sesuai dengan akal sehat, hati nuraninya serta pedoman Allah dan Rasul-Nya. 


\section{Daftar Pustaka}

Ali Mudhafir, 1992, Kamus Istilah Filsafat. Liberty, Yogyakarta.

Azyumardi Azra, 1987, Antara Kebebasan dan Keterpaksaan Manusia, dalam Insan Kamil: Konsepsi Manusia Menurut Islam, ed. Dawan Rahadjo, Grafiti Pers, Jakarta.

Bagoes, Lorens, 1992, Terminologi dan Klasifikasi Tema-tema Dasar, Tim LITBANG PIJAR, Yogyakarta.

Carrel, Alexis, 1987, Misteri Manusia, Terj. Kania Rusli, Remaja Karya, Bandung.

Iqbal, M., 1966. Membangun Kembali Pikiran
Agama dalam Islam, Tinta Mas, Jakarta.

Lili Tjahyadi, 1991, Hukum Moral : Ajaran Immanuel Kant Tentang Etika 、 dan Imperatif Kategoris, Kanisius, Yogyakarta.

Mudji Sutrisno dan Budi Hardimas, 1992, Para Filsuf Penentu Gerak Zaman, Kanisius, Yogyakarta.

Runes, Dagobert D., 1979, Dictionary of Philosopy, Litle Field, Adam and Co, New Jersey.

Sudiardjo, 1993, Catatan Kuliah Filsafat Etika. Titus, Smith dan Nolan, 1984, Persoalanpersoalan Filsafat, Bulan Bintang, Jakarta.

Van derWeij, 1988,Filsuf-filsufBesarTentang Manusia, Gramedia, Jakarta. 